\title{
FORMASI PUBLIC SPHERE DALAM MASYARAKAT \\ TRANSISIONAL \\ Studi Kasus Penyusunan Peraturan Daerah Nomor 3 Tahun 2007 \\ Tentang Limbah Padat di Kabupaten Luwu Timur, Provinsi \\ Sulawesi Selatan
}

\author{
Jannus Timbo Halomoan Siahaan \\ Alumni S2 Ilmu Manajemen Komunikasi Politik Universitas Indonesia 2007 \\ email: jannus_siahaan@yahoo.com
}

\begin{abstract}
ABSTRAK
Ruang publik yang dipopulerkan oleh Jurgen Habermas adalah hasil dari tinjauan realitas masyarakat Eropa abad ke-18. Dalam karyanya, Habermas menyebutkan bahwa kapitalisme pada saat itu berhasil membebaskan masyarakat Eropa dari ketergantungannya atas pengaruh feodalisme yang diberlakukan oleh gereja dan kekuasaan monarchy, yang bentuknya adalah sebuah ruang diskusi masyarakat yang ditujukan untuk mengkritisi kekuasaan tradisional (Gereja dan Kerajaan). Dengan kata lain, kekuatan kapitalisme berhasil menciptakan ruang perdebatan sosial yang dulunya dipengaruhi oleh kekuatan feodal hingga beralih ke wilayah sosial yang bebas dari dominasi kekuasaan feodal dimana di ruang publik tersebut masyarakat memiliki hak dalam memberikan kritik terhadap persoalan-persoalan kemasyarakatan. Jika di Eropa perkembangan ranah publik dipengaruhi oleh perkembangan kapitalisme, lalu bagaimana dengan pelaksanaan ranah publik di masyarakat transisional di Indonesia atau khususnya di masyarakat Luwu Timur? Makalah ini ingin menggali bagaimana pelaksanaan ruang publik sebagai sebuah konsep pada masyarakat transisi, khususnya di wilayah Luwu Timur khususnya terkait dengan proses pembuatan sebuah Peraturan Daerah No. 03 Tahun 2007 tentang Limbah Padat Berbahaya. Hasil penelitian di lapangan menunjukkan bahwa masyarakat masih mengalami kesulitan dalam mengakses informasi yang berkaitan dengan kebijakan terkait kehidupan publik secara riil. Pada saat bersamaan, pemerintah sendiri juga kesulitan dalam mendistribusikan informasi yang sesungguhnya dibutuhkan oleh masyarakat. Pemerintah, DPRD atau masyarakat Luwu Timur memang telah menyepakati untuk memberikan ruang diskusi kepada publik terkait pembuatan peraturan pengelolaan limbah padat tersebut. Namun ternyata dalam implementasinya tidak juga ditemukan cara yang sesuai sejak dari proses perumusan hingga sosialisasi terhadap sebuah peraturan daerah.
\end{abstract}

Kata kunci: ruang publik, masyarakat transisi

\begin{abstract}
The public sphere popularized by Jurgen Habermas is the result of a review of the reality of 18th century European society. In his work, Habermas mentions that capitalism at that time succeeded in liberating European society from its dependence on the influence of feudalism imposed by the church and monarchy, whose form was a community discussion room aimed at critiquing traditional power (Church and Kingdom). In other words, the power of capitalism has succeeded in creating a space of social debate that was
\end{abstract}


once influenced by feudal power until it switched to a social area free from the domination of feudal power where in that public sphere society has a right in giving criticisms of social problems. If in Europe the development of the public sphere is influenced by the development of capitalism, then what about the implementation of the public sphere in transitional society in Indonesia or especially in the East Luwu community? This paper seeks to explore how the implementation of public space as a concept in transitional society, especially in the East Luwu region in particular related to the process of making a Regional Regulation no. 03 of 2007 on Hazardous Solid Waste. The results of field research indicate that people are still having difficulty in accessing information related to policies related to public life in real terms. At the same time, the government itself also difficulties in distributing information that is actually needed by the community. The government, the DPRD or the people of East Luwu have indeed agreed to provide a discussion space to the public regarding the making of the solid waste management regulation. However, the implementation did not find the appropriate way from the formulation process until the socialization of a local regulation.

Keywords: public sphare, transitional society

\section{PENDAHULUAN}

Terbukanya ruang demokrasi pasca kejatuhan rezim Orde Baru telah membawa Indonesia ke dalam masa transisi demokrasi yang menarik. Pergantian kekuasaan dan otoritarianisme ini juga membawa perubahan yang signifikan, yaitu dari masyarakat feodal menuju masyarakat demokratis. Proses transisi dan perubahan ini salah satunya, ditandai dengan makin banyak dan luasnya ruang publik (public sphere). Ketika kekuasaan Orde Baru runtuh, public sphere terbuka seiring meningkatnya partisipasi publik. Tapi pada rezim otoritarianisme berkuasa, public sphere sengaja ditiadakan untuk meminimalisir gejolak dan melanggengkan kekuasaan. Partisipasi publik ini semakin terlihat dengan menguatnya pengawasan publik terhadap kinerja pemerintah (Habermas, 1989).
Dengan terbukanya ruang demokrasi ini, otoritas negara lambat laun semakin menyempit dan public sphere semakin meluas. Partisipasi warga yang secara luas berpartisipasi langsung dalam pengambilan keputusan publik dapat mendorong partisipasi menjadi lebih bermakna. Namun, masyarakat Indonesia belum sepenuhnya dapat melepaskan budaya feodalisme dan berubah menjadi masyarakat yang rasional. Fenomena ini sangat terlihat jelas dalam konteks Otonomi Daerah, terutama di daerahdaerah di pelosok Indonesia. Pengambilan kebijakan seringkali didasarkan pada kepentingan privat semata dan tidak didasarkan pada kepentingan public. Padahal, ruang publik (public sphere) yang sehat selalu menuntut dilakukannya perimbangan. Peran partispasi warga masyarakat dalam penentuan kebijakan (policy) semestinya dihargai dan diberi ruang aktualisasi yang bebas. 
Daerah-daerah yang masih mempertahankan budaya feodalisme tersebut, salah satunya, adalah Kabupaten Luwu Timur, Sulawesi Selatan. Masyarakat di daerah ini masih menganut sistem patriarki dimana laki-laki lebih dominan daripada perempuan dalam pengambilan keputusan dan agama masih menjadi hukum yang hakiki. Selain itu, masyarakt Luwu Timur juga masih belum dapat menjadi penentu pengambilan keputusan, terutama yang menyangkut kepentingan-kepentingan publik. Sejauh ini, ruang publik (public sphere) sebagai wadah aktualisasi dan partisipasi warga negara nyaris belum dapat diwujudkan secara adil dan demokratis.

Fenomena tersebut terlihat dalam proses pembuatan Peraturan Daerah (Perda) Nomor 03 Tahun 2007 tentang Limbah Padat. Dalam proses pembahasan Rancangan Peraturan Daerah (Ranperda)-nya, porsi konsultasi publik hanya diberikan kepada Kepala Desa dan anggota Dewan Perwakilan Rakyat Daerah (DPRD) Kabupaten Luwu Timur. Adapun publik atau masyarakat setempat tidak dilibatkan. Namun begitu, masyarakat juga enggan untuk menuntut hak politik mereka karena masih menganggap bahwa bupati ataupun pimpinan DPRD adalah raja atau turunan bangsawan yang perintahnya adalah sabda. Hal ini bertentangan dengan sistem demokrasi di mana masyarakat seharusnya menjadi kekuatan determinan dalam sebuah public sphere guna menghasilkan kebijakan-kebijakan yang bermanfaat.

Tulisan ini memberikan gambaran tentang formasi public sphere dalam perumusan Perda Nomor 03 Tahun 2007 Tentang Limbah Padat di masyarkat transisional. Dalam tulisan ini akan dipaparkan seperti apa Perda Nomor 03 Tahun 2007 tentang Limbah Padat itu dirancang, dirumuskan, dan disosialisasikan ke masyarakat Luwu Timur, Sulawesi Selatan dalam konteks public sphere.

\section{METODE PENELITIAN}

Penelitian ini menggunakan jenis penelitian deskriptif kualitatif yang bertujuan untuk menjelaskan fenomena sedalam-dalamnya melalui pengumpulan data sedalam-dalamnya baik melalui wawancara mendalam, FGD maupun observasi; di samping menggunakan data-data sekunder. Penelitian ini tidak melakukan generalisasi terhadap populasi tertentu namun lebih menekankan pada kedalaman analisisnya.

\section{HASIL DAN PEMBAHASAN}

\section{Pemikiran Habermas Tentang Public sphere}

Adalah sosiolog Jerman, Jurgen Habermas, yang mula-mula memperkenalkan istilah "public sphere" (ruang publik). Konsep ini ditulisnya pertama kali pada tahun 1962 dalam bahasa Jerman (oeffentlichkeit). Baru pada tahun 1989, atau tepatnya dua puluh tujuh tahun kemudian tulisannya diterjemahkan ke dalam bahasa Inggris dengan judul "The Structural of the 
Public sphere: An Inquiry into a Category of Bourgeois Society. Ruang public yang dimaksud Habermas dalam karyanya tersebut pada dasarnya merupakan ruang yang tercipta dari kumpulan orang-orang tertentu (private people)-dalam konteks sebagai kalangan borjuis, yang diciptakan seolah-olah sebagai bentuk penyikapan terhadap otoritas publik.

The bourgeois public sphere may conceived above all as the sphere of private people come together as a public; they soon claimed the public sphere regulated from above againts the public authorities themselves, to engage them in a debate over the general rules governing relations in the basically privatized but publicly relevant sphere of commodity exchange and social labor. (Habermas, 1962/1989:27)

Gagasan konsep public sphere yang diajukan oleh Habermas ini muncul didasarkan pada realitas yang terjadi pada fase perkembangan kapitalisme di Eropa pada abad ke 18 dan 19. Secara garis besar, Habermas berpandangan bahwa pesatnya penyebaran kapitalisme di Inggris yang ditandai dengan jumlah kaum pedagang yang semakin banyak dan kekuatan modal yang semakin besar telah berhasil memperlemah pengaruh kekuatan feodal para pemimpin agama (gereja) dan anggota keluarga kerajaan yang pada masa sebelumnya mendominasi tata kehidupan publik di Inggris. Realitas ini ditandai dengan maraknya perkembangan dunia sastra yang ditampilkan dalam teater, novel, karya tulis dan seni lukis yang berisi kritik, serta munculnya grup-grup diskusi dalam warung-warung kopi (coffee houses) dan salon pada masa itu.

Habermas juga mengemukakan bahwa beberapa surat kabar yang diterbitkan oleh kaum pemodal pada abad 18 telah berhasil menyuarakan reformasi terhadap parlemen. Institusi pers yang didukung kaum pemodal, menginginkan agar representasi masyarkaat di parlemen mendukung ekspansi pasar. Akibatnya, berkembanglah kehidupan politik oposisi yang kemudian merangsang adu argumentasi dan perdebatan di dalam masyarakat. Semua ini kemudian mendorong lahirnya "kebijakan rasional" (Webster, 1995)

Dalam esainya, The Public sphere, Habermas mengatakan bahwa ruang public merupakan wilayah sosial yang bebas dari sensor dan dominasi. Semua warga masyarakat pada prinsipnya boleh memasuki ruang tersebut. Mereka sebenarnya orangorang privat yang percakapnya membentuk sebuah publik. Dalam diskusi tersebut, mereka melepaskan diri dari berbagai atribut sosial dan budaya serta kepentingan ekonomi tertentu. Sehingga mereka bukan lagi sebagai pebisnis atau professional, juga bukan pejabat dan politikus. Masing-masing dari mereka berfungsi sebagai pendidik, dan apa yang mereka diskusikan adalah soal-soal kepentingan umum. Public sphere merupakan sebuah ruang di mana warga negara saling bertukar gagasan dan mendiskusikan sebuah masalah 
untuk meraih sebuah kesepakatan dalam suatu kepentingan bersama.

"The public sphere is domain of our social life where such a things as public opinion can be performed (where) citizens...deal with matters of general interest without being subject to coercion...(to) express and publicize their views". (Habermas, 1997).

Dalam public sphere dibicarakan mengenai peristiwa yang sedang terjadi di masyarakat: isu politik, sosial dan budaya apa saja yang sedang dihadapi masyarakat pada saat itu. Public sphere memberikan kesempatan agar masyarakat tidak pasif terhadap informasi yang diterima. Dengan demikian, di dalam ruang public itu pula, setiap orang memiliki kesempatan untuk terlibat dengan berbagai isu actual, khususnya dalam bertukar pendapat, atau dengan kata lain, memainkan peranan tertentu dalam proses mencapai konsensus ataupun kompromi terhadap isu tertentu serta menyepakati agenda aksi bersamanya.

Konsep public sphere sangat berguna untuk mempelajari bagaimana masyarakat modern yang berada dalam sistem demokrasi liberal. Konsep ini dapat menjelaskan tentang bagaimana warga negara meraih sebuah consensus bersama untuk merumuskan apa yang terjadi dan mengakomodir kepentingannya dalam sebuah keputusan publik.

Habermas mengatakan kebebasan berbicara adalah syarat utama agar terjadi komunikasi umum dan diskursus tingkat tinggi, walau mungkin ini sulit dilakukan. Karena itu, menurut Habermas, ada empat kondisi ideal agar terjadi kebebasan berbicara itu, yaitu:

a. Situasi yang mendukung untuk mengemukakan pendapat.

b. Semua individu mendapatkan akses yang sama untuk berbicara.

c. Kekuasaan dalam forum tersebar merata.

d. Dialog yang rasional (Littlejhon: 1996).

Menurut Habermas, ruang publik baru akan berfungsi secara efektif bila informasi yang dikemukakan di dalamnya adalah informasi yagn berkualitas dan mudah di dapat, dan bila informasi yang didapatkan adalah informasi yang dapat diandalkan (reliable) dan cukup untuk sebuah perdebatan publik sehingga mendukung terbentuknya diskusi berkualitas. Sedangkan informasi yang buruk akan menghasilkan perdebatan yang buruk dan berakibat pada konsensus publik yang buruk pula. Karena itu menurut Habermas, ada tiga prinsip utama bagi sebuah ruang publik, yaitu akses yang mudah terhadap informasi, tidak ada perlakuan istimewa (priviledge) terhadap peserta diskusi, dan peserta mengemukakan alasan rasional saat berdiskusi dalam mencari consensus (Roper dalam Toulouse, 1998).

\section{Substansi Perda Nomor 03 Tahun 2007}

Berdasarkan persetujuan bersama antara Dewan Perwakilan Rakyat Daerah (DPRD) Kabupaten Luwu Timur dan Pubati Luwu Timur, 
maka terbitlah peraturan daerah tentang pengelolaan limbah padat. Perda ini dimaksudkan untuk mengatur peredaran limbah padat yang bernilai ekonomis dengan tetap menjaga kualitas lingkungan sesuai dengan fungsinya demi mewujudkan suatu lingkungan hidup yang sehat. Sehingga terwujudlah lingkungan yang selaras, serasi, dan seimbang guna mendukung pembangunan yang berkelanjutan.

Kalau melihat substansi pokok yang terangkum dalam perda Nomor 03 Tahun 2007 itu, di sana dijelaskan bahwa:

a. Setiap Badan Usaha yang akan melakukan kegiatan pengelolaan limbah padat selain Limbah B3, harus memiliki persetujuan dari Bupati sesuai dengan ketentuan perundang-undangan yang berlaku.

b. Pengaturan Peredaran Limbah Padatdan Limbah B3 diatur lebih lanjut dengan Peraturan Bupati.

c. Pengaturan peredaran Limbah Padat akan diatur oleh Bupati setelah memperoleh izin dari kementrian lingkungan hidup.

d. Persetujuan bupati itu dikeluarkan setelah berkonsultasi dengan DPRD

Sedangkan tata laksana perizinannya ditetapkan antara lain:

a. Setiap kegiatan Badan Usaha yang melakukan kegiatan pengelolaan dan Peredaran Limbah Padat wajib memiliki izin. b. Izin itu diberikan oleh bupati dan dapat dilimpahkan kepada Dinas/Badan/Kantor.

c. Izin untuk limbah kategori bahan berbahaya dan beracun dikeluarkan oleh Pemerintah Pusat sesuai dengan Peraturan Perundang-undangan yang berlaku.

Persyaratan untuk memperoleh izin mengelolah limbah itu antara lain ditetapkan:

a. Memiliki akta pendirian sebagai Badan Usaha yang telah disahkan oleh instansi yang berwewenang.

b. Nama dan alamat Badan Usaha yang memperoleh izin.

c. Kegiatan yang dilakukan.

d. Lokasi tempat kegiatan.

e. Nama dan alamat penanggung jawab kegiatan.

f. Bahan baku dan proses kegiatan yang dilakukan.

g. Memiliki izin usaha.

h. Memiliki Dokumen Pengelolaan dan Pemantauan Lingkungan.

i. Memiliki Izin Gangguan (HO) Segala biaya untuk memperoleh izin dan persetujuan dibebankan kepada pemohon. Beban biaya pemohonan izin meliputi biaya studi kelayakan teknis untuk proses perizinan. Untuk pembinaan dan pengawasan yang dilakukan oleh instansi teknis terkait dibebankan kepada APBD. Seperti juga perda yang lain, dalam Perda Nomor 03/2007 itupun ditetapkan sanksi-sanksi yang antara lain:

a. Bupati dapat menghentikan sementara kegiatan operasi 
terhadap pemegang izin apabila terjadi pelanggaran yang dapat membahayakan lingkungan hidup.

b. Pemegang izin yang tidak melaksanakan kewajibannya dapat dilakukan pencabutan izinnya.

c. Pemegang izin yang melakukan pengrusakan lingkungan dikenakan sanksi sesuai peraturan perundang-undangan yang berlaku.

d. Setiap orang atau Badan Usaha yang melakukan pengelolaan limbah padat tanpa memiliki izin sebagaimana dimaksud pasal 6 ayat (1) diancam pidana kurungan paling lama 3 (tiga) bulan atau denda paling banyak Rp. 50.000.000 (lima puluh juta).

Berdasarkan peraturan Bupati Luwu Timur No. 06 Tahun 2007, tentang pelaksanaan peraturan daerah Kabupaten Luwu Timur No. 03 Tahun 2007 itu, antara lain ditetapkan bahwa yang ditunjuk untuk melaksanakan perda No. 03 Tahun 2007 itu adalah Kepala Dinas Pertambangan, energi dan Lingkungan Hidup. Instansi ini melaksanakan sosialisasi kepada masyarakat dalam pelaksanaan Peraturan Daerah yang dimaksud. Selain itu, instansi ini juga diberi tugas untuk menyusun petunjuk teknis pelaksanaannya dengan unit kerja terkait dan selanjutnya mengusulkan untuk ditetepkan keputusan bupati.

\section{Menyoroti Proses Perumusan dan Sosialisasi Perda No. 03 Tahun 2007}

Secara konseptual, perda itu dibuat berdasarkan formulasi bahwa sebelum dan sesudah produk peraturan dibuat harus ada proses sosialisasi yang cukup kepada setiap anggota masyarakat. namun dalam prakteknya, proses perumusan dan sosialisasi Perda No. 03 Tahun 2007 itu dipenuhi oleh munculnya klaim dan opini yang pro dan kontra. Pro dan kontra yang muncul itu tidak terkait persoalan tujuan dan manfaat perda itu, melainkan lebih pada siapa yang berinisiatif atas pembuat Perda itu. Selain itu, juga, mempersoalkan, untuk kepentingan kelompok mana saja Perda itu dimunculkan, seberapa besar porsi manfaat yang kembali ke masyarakat luas dibandingkan dengan yang kembali kepada kelompok tertentu?

Hal lain lagi adalah tentang apakah perda itu sudah dirumuskan berdasarkan aturan-aturan yang mengharuskan adanya proses dengar pendapat dengan masyarakat atau Perda itu dibuat secara langsung dan tanpa sosialisasi?

Menurut Andi Hatta, Bupati Kabupaten Luwu Timur, Perda itu adalah sebuah payung hukum pengelolaan limbah padat yang kelahirannya dilaterbelakangi oleh aspirasi masyarakat atau untuk menampung kehendak public. Kalau misalnya limbah itu tidak dikelola dengan baik maka akan menjadi bomerang, baik bagi industry itu dan bagi masyarakat sekitar. 
Tentang proses pelibatan masyarakat dan sosialisasinya, menurut Andi Hatta, semua Perda di Luwu Timur itu ketika akan dirumuskan dan ketika dibahas sudah membuka ruang sharing dengan masyarakat. sharing inilah yang akan digunakan untuk menggali masukanmasukan dari masyarakat dalam rangka meningkatkan bobot Perda yang akan dibuat. Masih menurut Andi Hatta, Perda No. 03 Tahun 2007 ini munculnya bukan dari pemerintah, akan tetapi dari bawah. Pemerintah menangkap kegelisahan masyarakat lalu muncul kesepakatan untuk membuat perda tentang limbah padat itu. Perda ini dibuat dengan memperhatikan tiga aspek penting, yaitu: aspek pengaturan, aspek keadilan, dan aspek finansial.

Terkait dengan sosialisasi perda, bupati sendiri menyadari bahwa sosialisasi sudah dilakukan, namun belum efektif. Bentuk sosialisasi yang pernah dilakukan antara lain: pemasangan spanduk, foto-foto, dan poster. Fakta di lapangan menunjukkan bahwa aktivitas sosialisasi seperti ini masih terbatas. Karena itu Pemda setempat bermitra dengan pihak-pihak tertentu di masyarakat untuk bisa terlibat dalam proses sosialisasi ini.

Senada dengan pendapat bupati, pimpinan DPRD Kabupaten Luwu timur, A. Hassan Opu Tohatta, Mengatakan bahwa latar belakang dari perda ini adalah keinginan dari masyarakat untuk mengolah limbah padat secara baik dan dapat menghasilkan nilai ekonomi. Menurut dia, perda ini sebelumnya sudah digodok oleh pihak pemerintahan dan kalangan industri (PT. Inco). Setelah itu disosialisasikan kepada masyarakat dan perusahaan.

Sejauh yang diketahui oleh DPRD ini, pihak masyarakat memang belum ada yang protes atas perda tersebut. Namun demikian, DPRD Kabupaten Luwu Timur khususnya Komisi III akan mengeluarkan pendekatan dan memberikan pengertian tentang keberadaan Perda itu. Sehingga segala sesuatunya bisa dilakukan dengan aman dan tidak merugikan masyarakat, tidak merugikan perusahaan, dan tidak merugikan pemerintah sebagai pengatur kabupaten.

Menurut Rosmiaty Alwi, Sekretaris Dewan di DPRD Luwu timur, Pansus DPRD sebelumnya telah disosialisasikannya terlebih dahulu kem asyarakat agar tidak terjadi halhal yang tidak diinginkan. Sayangnya, sosialisasi itu dilakukan setelah pembahasan. Bentuk sosialisasi itu, menurut dia, dilakukan dalam bentuk pertemuan dengan tokoh masyarakat, pemerintah dan pengusaha. Karena itu, masih menurut Rosmiaty, sebaiknya sosialisasi Perda ini sebelum melakukan pembahasan. Pansus harus menampung aspirasi terlebih dahulu sebelum melakukan pembahasan.

Kasro Asrie, Anggota Pansus DPRD, berpendapat bahwa Perda itu diterbitkan dengan tujuan untuk mengatur pemanfaatan limbah yang tidak merusak lingkungan. Menurut dia, usulan Perda itu merupakan pemikiran banyak orang yang berniat melakukan investasi terhadap 
pengolahan limbah sehingga regulasi yang kita bikin adalah bagaimana para penyelenggara atau yang terkait dengan itu memberikan kontribusi kepada daerah.

Perda itu, menurut dia, penting sekali bagi masyarakat karena didalamnya terkait dengan penyelamatan lingkungan dan berkontribusi kepada daerah atau masyarakat. usulan tentang perda itu sama sekali tidak datang dari perusahaan tambang. Menurutnya, perda itu sudah disosialisasikan dalam bentuk pertemuan dengan pihak eksekutif dan sebagian masyarakat. bahwa kemudian hasilnya menimbulkan pro dan kontra di dalam masyarakat, maka pihak eksekutiflah yang harus bertanggung jawab untuk melakukan sosialisasi ulang.

Lain pejabat, lain pula masyarakat. kondisi inilah yang muncul ketika menyimak suara-suara tentang Perda No. 03 itu dari pemerintah atau pejabat dan dari masyarakat atau LSM (stakeholder). Berdasarkan hasil wawancara peneliti dengan kelompok-kelompok di masyarakat dari kalangan masyarakat umum, wartawan, dan aktivis LSM, ternyata di sana ditemukan perbedaan klaim sebagai akibat dari adanya kesenjangan komunikasi (communication gap) yang tidak terjembatani.

Masyarakat umum sudah mendengar wacana yang terkait dengan limbah padat itu, namun belum mengetahui apakah Perda itu sudah dirumuskan atau belum. Diwacanakan dalam arti bahwa persoalan limbah padat dan proses pengelolahaannya telah menjadi perbincangan umum di dalam masyarakat. ini karena di dalamnya ada nilai-nilai ekonomi yang menjanjikan.

Masyarakat berskesimpulan bahwa Perda tersebut memang dilatarbelakangi oleh tuntutan mayarakat lalu pemerintah menanggapinya sebagai peluang ekonomi dengan tujuan untuk menambah pendapatan daerah. Sayangnya, terbitnya Perda itu dikesankan oleh masyarakat hanya untuk melindungi kepentingan sebuah perusahaan saja dan tidak berlaku untuk umum.

Meskipun masyarakat tidak tahu apa isi perda itu dan bagaimana Perda itu disosialisasikan, tapi masyarakat tetap setuju sejauh itu berdampak positif kepada masyarakat secara langsung. Pendapat kalangan LSM pun tak jauh berbeda. Sulnawir dan Buhari yang mewakili kelompok LSM lingkungan, berkesimpulan bahwa persoalan pengelolaan limbah pasat ini memang sudah lama menjadi isu di masyarakat. namun prakteknya pembuatan perda-nya, LSM tidak dilibatkan. Namun begitu, menurut Sulnawir, pihak LSM pun punya tanggapan sangat apresiatif terhadap kehadiran Perda itu. Cuma, kata mereka, lahirnya perda itu mestinya perlu mendapat input dari masyarakat. di samping itu, keberpihakan kalangan DPRD terhadap kepentingan masyarakat pun harus dibuktikan. Yang tak kalah pentingnya lagi adalah melihat tenaga ahli yang tahu banyak tentang limbah padat. 
Proses pembahasannya dan proses sosialisasinya pun, menurut mereka dinilai sangat tertutup. Selama dalam proses pembahasan dan proses sosialisasi tidak satu pun LSM lingkungan yang dilibatkan. Meski begitu, mereka setuju dengan substansi yang terkandung dalam perda itu. Harapannya, perda ini tidak merugikan satu pihak dan tidak hanya menguntungkan satu pihak. Namun begitu, kalangan ini tidak merugikan satu pihak dan tidak hanya menguntungkan satu pihak.

Namun begitu, kalangan LSM pun tetap mendukung. Hanya memang proses lahirnya perda itu yang dinilai kurang matang dan bisa saja merugikan pihak-pihak lain. Mestinya, menurut kalangan LSM, perlu ada jalan terbaik, win-win solution, antara pihak swasta dan masyarakat yag diatur dengan Perda dan pihak pemerintahan sebagai pengaturnya. Mengundang keterlibatan masyarakat, menurut kalangan LSM, itu sangat penting. Alasannya adalah karena masyarakatlah yang diatur. Jika masyarakat yang diatur tidak dilibatkan, tentunya sah-sah saja kalau masyarakat menggugat. Dan jika hal itu terjadi, harapan mereka, pemerintah perlu bersedia melakukan perubahan isi Perda.

Kalangan wartawan pun berpendapat bahwa Perda Nomor 03 Tahun 2007 itu memang sudah melibatkan kalangan pers dan sebagian tokoh masyarakat. hanya saja sosialisasinya, baik sebelum dan sesudah pembahasan dinilai masih kurang efektif.
Sulnawir, salah seorang wartawan yang mengetahui banyak bagaimana perda itu dibuat, mengakui bahwa dalam pembahasan Perda itu di gendung DPRD, memang mengundang Pers dan Tokoh masyarakat. Tapi itu hanya terjadi pada saat pembahasan. Menurut dia, Perda itu merupakan buah pemikiran pihak eksekutif dan legislatif. Pandangan sedikit berbeda datang dari pihak PT. Inco, perusahaan tambang satu-satunya yang dilihat sebagai biang dari kemunculan Perda tersebut. Menurut Laode Ichman, Staf Communitiy Relations PT. Inco di Sorowako, Perda soal limbah itu sebenarnya lahir dalam konteks untuk kepentingan pendapatan daerah. Bukan masyarakat atau perusahaan (PT. Inco). Sebab, kalau dikaitkan dengan kepentingan masyarakat, Laode justru melihat tidak ada ekspektasi masyarakat untuk hal itu, karena hal ini hanya terkait dengan sekelompok pengusaha yang memiliki modal besar dan teknologi yang tentunya tidak dimiliki oleh kebanyakan orang.

Dalam hal ini Laode menegaskan bahwa PT. Inco tetap berpegang teguh kepada ketentuan bahwa slag dikategorikan sebagai bahan yang tidak boleh dimanfaatkan untuk publik eksternal, karena hanya KLH yang berhak mengeluarkan izin. Sesuai PP 18/1999, limbah padat berupa slag nickel masuk kategori B3, karenanya harus ada izin pemanfaatan dai KLH. Inco memiliki izin dari KLH untuk memanfaatkan slag sebagai civil material, antara lain untuk pengerasan jalan di dalam wilayah Kontrak 
Karyanya. Di luar itu harus seizin KLH.

\section{Analisis Formasi Public sphere dalam Masyarakat Transisional}

Seperti yang telah diuraikan sebelumnya, konsep public sphere memberikan kita arti sebagai sebuah ruang di mana warga negara saling bertukar gagasan dan mendiskusikan sebuah masalah untuk meraih sebuah kesepakatan dalam sebuah kepentingan bersama. Atau dengan bahasa yang lebih sederhana, ruang publik bisa dipahami sebagai ruang yang menyediakan dan melibatkan publik secara lebih luas dalam mendiskusikan realitas yang ada. Ruang publk ini bersifat independen dari pemerintahan dan kekuatan ekonomi, sehingga dengan begitu ruang public memberikan kesempatan kepada masyarakat luas untuk menyebarkan informasi dan mendebat informasi yang disampaikan. Bagi para ahli sosial-politik, konsep ini dapat digunakan untuk menjelaskan tentang bagaimana warga negara meraih sebuah Konsensus bersama untuk merumuskan apa yang terjadi dan mengakomodir kepentingan dalam sebuah keputusan publik. Lebih lanjut, Harbermas sendiri berpendapat, ruang publik yang menjadi pemicu lahirnya kekuasaan rasional (pengilhaman politik) yang hanya berkembang pada masyarakat modern, yang dalam konteks eropa muncul pada akhir abad ke-17.

Pertanyaan yang penting untuk dimunculkan di sini adalah bagaimana menjelaskan konsep public sphere di masyarakat transisional, katakanlah, dalam hal ini masyarakat Kabupaten Luwu Timur? Sejauhmanakah konsep ini bisa menjelaskan? Model ruang publik seperti apakah yang dimiliki oleh masyarakat dalam periode transisional seperti Luwu Timur?

Secara umum, masyarakat transisional menghadapi problem yang antara lain bisa dijelaskan sebagai berikut: pertama, adanya sisa-sisa mentalitas feodal yang masih melekat kuat di kalangan pejabat dan masyarakat. untuk konteks Indonesia, kekuatan yang mendukung reformasi pasca Soeharto terpolarisasi menjadi bagian yang terpecah-pecahkan sehingga tidak terjadi konsolidasi yang diperlukan untuk mendukung perubahan ke arah demokrasi secara signifikan. Ini terjadi dari mulai level nasional sampai ke level regional.

Dalam konteks pembentukan public sphere, terpolarisasinya kekuatan reformasi ini bisa menjadi ganjalan tersendiri. Ganjalan ini bisa dalam bentuk, misalnya saja, konflik yang timbul akibat munculnya prokontra terhadap kekuatan status quo demi kepentingan pribadi atau demi kepentingan kelompok tertentu. Jadi, pro dan kontra yang muncul bukan demi demokrasi, melainkan demi keuntungan (vested interest) tertentu atau demi kepentingan untuk mendekati kekuasaan. Padahal, seperti yang disinggung Harbermas di muka, perjuangan membebaskan diri dari pengaruh negara adalah unsur penting dari sebuah ruang publik.

Masyarakat transisional dihadapkan pada dua kelompok yang 
sama-sama kuat. Satu kelompok menginginkan perubahan tapi kelompok lain justru ingin menghambat perubahan yang diinginkan. Di tingkat pejabat atau birokrasi, tidak semua memiliki kesadaran untuk memperkuat konsolidasi yang diperlukan untuk mendukung perubahan dengan meninggalkan tradisi feodalisme. Masih banyak kelompok atau tradisi yang lama prakteknya justru ingin memperkuat akar tradisi feodalimse. Ini terlihat dari kesulitan yang dirasakan masyarakat untuk memperoleh informasi atau pelayanan kepublikan yang diperlukan dengan birokrasi yang dirancang sedemikian tertutup. Dari sisi masyarakat sendiri juga begitu. Masyarakat memang menginginkan perubahan tapi pada saat yang sama masih mempraktekkan tradisi-tradisi yang tidak mendukung untuk perubahan, ini terlihat dari rendahnya minat masyarakat untuk mencari informasi, membaca informasi yang bermutu, membuka dialog-dialog tentang urusan kepublikan, dan lainlain.

Kenyataan ini bila dikaitkan gagasan public sphere, tentu akan menjadi ganjalan. Seperti yang sudah dijelaskan di muka, bahwa ruang public itu akan menjadi tempat memperbincangkan persoalan kepublikan yang bermakna apabila masyarakat terbekali oleh informasi yang akurat tentang urusan kepublikan. Kalau informasi yang kredibel dan aturan ini tidak dimiliki, maka perbincangan yang muncul di ruang publik mungkin hanya sebatas obrolan yang lebih dekat pada pengertian gosip atau desas-desus, bukan sebuah perbincangan yang bermakna.

Di samping itu, kalau mengacu pada konsep public sphere, keberadaan orang-orang yang datang ke ruang publik itu adalah orang-orang dalam kapasitas privat. Ini juga belum sepenuhnya ada di masyarakat transisional. Orang-orang yang datang di ruang publik umumnya adalah orang-orang dengan kapasitasnya masing-masing: kapasitas sebagai professional, sebagai pejabat, sebagai masyarakat, sebagai pebisnis, dan lainlain. Masyarakat transisional belum sepenuhnya bisa meninggalkan tradisi mengkasta-kastakan orang berdasarkan status sosial atau ekonomi dalam seluruh wilayah kehidupannya.

Kedua, peranan media. Media dalam masyarakat transisi tidak seluruhnya menggerakkan masyarakat untuk pro-demokrasi. Padahal apapun bahasannya, media berperan penting dalam menciptakan opini publik. Langkah media dalam masyarakat transisional dihadapkan pada tantangan di mana media harus bisa memainkan peranannya untuk kepentingan idealisme dan kepentingan bisnis secara seimbang. Di sisi lain media juga dihadapkan pada persoalan selera pasar yang masih banyak meminati informasi berbau "sekedar hiburan" yang signifikannya sangat kecil dalam membekali masyarakat dengan informasi-informasi yang penting dan bermanfaat untuk mereka.

Kalau mengacu pada pendapat James Curran (2002; 247), media yang bida dikatakan pro-demokrasi itu 
antara lain telah memenuhi syaratsyarat:

a. media should empower people by enabling them to explore where their interest lies.

b. Media should support sectional group identities and assist the functioning of organizations necessary for the effective representation or group interests,

c. Media should sustain vigilant scrutiny of government and centres of power,

d. Media should provide a source of protection and redress for weak and unorganized interests, and

e. Media should create the conditions for real societal agreement or compromise base on an open discussion of differences rather than a contrived consensus based on elit dominace.

Undang-undang No. 40 tahun

1999 tentang Kebebasan Pers merupakan upaya konstitusional yang penting untuk dijadikan acuan. Pasal 6 UU Kebebasan Pers secara jelas mengisyaratkan nilai-nilai demokrasi yang harus diemban oleh pers nasional, yaitu:

a. Memenuhi hak masyarakat untuk mengetahui;

b. Menegakkan nilai-nilai dasar demokrasi, mendorong terwujudnya supremasi hukum, dan hak asasi manusia, serta menghormati kebhinekaan; c. Mengembangkan pendapat umum berdasarkan informasi yang tepat, akurat dan benar;

d. Melakukan pengawasan, kritik, koreksi, dan saran terhadap halhal yang berkaitan dengan kepentingan umum;

e. Memperjuangkan keadilan dan kebenaran.

Pada tingkat realitas di lapangan, memang sudah mulai tumbuh media-media yang berada dalam track untuk memperjuangkan demokrasi, kebenaran atau keberpihakan pada public. Banyak kasus korupsi yang terungkap melalui upaya media dalam mengangkat penyelewengan kekuasaan ke ruang publik. Tapi ini, untuk tingkat daerah, biasanya segera bisa dilawan dengan media lain yang berusaha untuk menjadi tandingannya.

Media masa idealnya menjadi arena yang bebas nilai dan netral. Tapi dalam prakteknya, media masih kerap menjadi saluran bagi gagasan-gagasan yang tidak bertentangan dengan kepentingan status quo atau pandangan kelompok dominan. Hal ini dapat terjadi karena sistem media dan komunikasi telah dikontrol sedemikian rupa sehingga menciptakan mekanisme perlindungan bagi penguasa dari berbagai kritisisme dan perlawanan masyarakat. demikian pula homogenisasi, telah menempatkan kawasan publik dalam posisi subordinate di hadapan penguasa dan pers diciptakan mendukung proses tersebut.

Menurut Habermas, pada awalnya media massa memang 
dibentuk dan menjadi bagian integral dari public sphere, akan tetapi pasca proses selanjutnya ia dikomersilkan dan menjadi komoditi (commodified) melalui distribusi secara massal dan dijual ke perusahaan periklanan, sehingga media massa menjadi jauh dari peran public sphere, kondisi inilah yang menyebabkan Habermas berpendapat bahwa media komersil jauh dari nilai-nilai public sphere.

Dengan kata lain, tantangan berat yang dihadapi media di masyarakat transisional, yaitu: a) tantangan untung menyeimbangkan idealism dan bisnis dan b) tantangan dalam menghadapi selera masyarakat yang masih meminati hiburan emosional belaka, telah menyulitkan media untuk berperan optimal dalam mencerdaskan masyarakat atau menyadarkan masyarakat akan hakhak publiknya atau bisa terhindar dri pertarungan kelompok elit tertentu.

Ketiga, minimnya fasilitas dan infrastruktur sosial yang dapat memfasilitasi masyarakat untuk mendapatkan informasi yang akurat, cepat dan mudah. ini pada gilirannya juga menyulitkan pihak eksekutif atau legislatif untuk mensosialisasikan kebijakan-kebijakan publiknya. Kenyataan ini telah melahirkan ruang publik yang kurang berbobot isi perbincangannya. Di masyarakat Luwu Timur, ruang publik memang muncul di rumah-rumah, tempat-tempat ibadah, warung-warung atau kawasan dekat lahan pertanian atau perkebunan. Di sini, mereka memperbincangkan persoalan kepublikan sebagai privat dan saling mempercayai. Namun karena informasi yang mereka miliki kurang akurat (berdasarkan teks atau pemberitaan) dan saluran informasinya masih jarang, maka akibatnya perbincangan mereka tidak sampai pada hasil dalam bentuk konsensus publik.

Keempat, peranan lembaga swadaya masyarakat atau masyarakat madani. Dari berbagai penelitian terungkap bahwa ada sejumlah kelompok yang menjadi aktor penting dalam perpolitikan Indonesia, terutama pasca Soeharto. Kelompok-kelompok itu antara lain: a) partai politik, b) birokrasi dan politik, c) media massa, d) pada cendekia atau mahasiswa, e) lembaga swadaya masyarakat atau organisasi kemasyarakatan. Kelompok ini berperan penting dalam percaturan politik di Indonesia.

Secara teoritis, sebetulnya masyarakat bisa berharap banyak dari peranan sejumlah lembaga swadaya atau kelompok masyarakat madani untuk mengisi beberapa celah kekurangan yang dimiliki media atau pemerintahan dalam hal mendistribusikan informasi atau pengetahuan yang selaras dengan semangat perubahan. Ini karena, mereka dinilai punya akses yang cukup untuk mendapatkan informasi kepublikan dan punya kapasitas yang memadai untuk menjadi trigger pembentuk ruang publik.

Namun dalam prakteknya, peranan ini belum bisa dilaksanakan secara optimal. Tentu ini karena ada persoalan-persoalan di lapangan yang mereka hadapi. Sebagian besar persoalan yang dirasakan sangat 
menghambat itu antara lain: a) dana, b) prioritas program, c) sumber daya manusia, dan d) dukungan masyarakat/pemerintah.

Di sejumlah kawasan, termasuk di Kabupaten Luwu timur, banyak LSM atau kelompok masyarakat madani yang tidak bisa berperan optimal untuk mentransfer isu-isu demokrasi atau sebagai agen perubahan karena mereka tidak punya dana, tidak mendapatkan dana, dan atau tidak bisa menciptakan sumber pendanaan yang mandiri, bahkan untuk kawasan tertentu, banyak di antara mereka yang beralih fungsi sebagai penyalur bantuan dari luar ke masyarakat.

Kalau dilihat dari programprogramnya, masalah pendemokrasian masyarakat bukan menjadi prioritas utama, ini terkait dengan realitas di lapangan di mana sebagian besar masyarakat di daerah masih sibuk berkonsentrasi mengurus masalahmasalah public yang bersifat fisik, seperti pembangunan jembatan, jalan urusan sembako, listrik, air bersih, dan lain-lain. Persoalan-persoalan demokrasi ini masih belum mereka rasakan. Ini tentu berbeda dengan konteks historis masyarakat Eropa yang dijadikan acuan dasar oleh Habermas terkait dengan gagasannya tentang public sphere.

Di luar perosalan itu, masalah yang tidak kalah seriusnya lagi adalah soal SDM atau tenaga yang handal, tidak semua LSM memiliki asset SDM yang benar-benar handal dan mengerti. Asset SDM itu sebagian besarnya hanya berada di tingkat pucuk pimpinan dan itu jumlahnya hanya sedikit. Sementara untuk tingkat manajerial dan operasional lapangan, beberapa LSM mengalami kekurangan SDM yang handal. Bahkan dari wawancara penelitian di lapangan, banyak tenaga di LSM yang semula hanya berniat untuk menjadikannya sebagai "tempat pelarian" dari problem sosial, terutama adalah sulitnya menemukan pekerjaan yang mereka inginkan dengan sertifikasi akademiki yang mereka miliki.

Yang tak kalah seriusnya lagi adalah dukungan masyarakat dan pemerintah. Masih banyak pejabat daerah yang menilai gagasan-gagasan yang dibawa LSM itu sebagai upaya untuk menjual persoalan publik melalui proposal bantuan kepada pemerintah untuk kepentingan kelompoknya. Memang ini pasti ada sebagian LSM yang melakukannya, tapi bila sudah muncul anggapan atau penilaian yang mengeneralisir ke semua LSM, tentu ini persoalan tersendiri. Begitu juga dengan masyarakat. mereka terkesan tidak digerakkan oleh keinginan untuk menjadikan LSM atau kelompok masyarakat madani sebagai mitra dalam upaya mendemokrasikan kehidupan sosial. Untuk beberapa kawasan di daerah tertentu, masyarakat malah minta dibayar, diberi fasilitas dan dilayani secara penuh apabila diajak untuk membicarakan persoalan kepublikan, entah dalam bentuk diskusi atau lainnya.

Kelima, kaum pemodal tetap menjadi raja. Pada kenyataannya, meskipun panji-panji demokrasi sudah 
dikibarkan, tapi peranan kaum pemodal dalam demokrasi tetap menjadi kunci. Kenyataan di masyarakat transisional yang tidak bisa dinafikan adalah adanya praktekpraktek membeli suara politik, membiayai publikasi media, membayar tokoh, memesan isu publik, membeli hukum, dan lain-lain. Sepintas memang proses yang terjadi adalah proses demokrasi. Tapi jika dilihat dari isi atau esensinya, demokrasi yang ditempuh adalah demokrasi yang tidak demokratis. Praktek ini lahir tentu karena adanya penegakan hukum yang masih lemah, mentalitas masyarakat yang masih transisional, dan resistensi kaum pemodal untuk ikut berpartisipasi dalam menciptakan iklim kehidupan politik dan sosial yang demokratis.

Itulah sebagian dan sekian persoalan di lapangan yang dihadapi oleh masyarakat transisional. Kalau membaca fenomena sosial yang terjadi di Kabupaten Luwu Timur, dengan mengacu pada konsep public sphere, di sana ditemukan poin-poin penting yang patut untuk dicatat. Ini antara lain bahwa:

Pertama, belum tercapainya klaim yang oleh Habermas disebut klaim komprehensibilitas. Artinya, belum ada proses komunikasi yang efektif dan dialogis antara publik dan pemerintahan. Habermas berpendapat bahwa setiap komunikasi yang efektif harus mencapai iklim ini. Dan orang yang mampu berkomunikasi dalam arti menghasilkan klaim-klaim itu disebut memiliki kompetensi komunikatif (Hardiman: 1993).
Kenyataan ini bisa terjadi karena beberapa hal, misalnya antara lain: a) kesenjangan mental, fisik dan psikologis antara pemerintah, legislatif dan masyarakat, b) minimnya fasilitas untuk saling bertukar informasi, dan c) kesadaran masyarakat untuk mendapatkan informasi dan kesadaran pemerintah atau legistlatif untuk mendistribusikan informasi masih rendah.

Bukti bahwa klaim komprehensibilitas itu belum tercapai seutuhnya dalam masyarakat Luwu Timur terkait dengan Perda No. 03 Tahun 2007 itu adalah munculnya kesenjangan komunikasi di mana masing-masing pihak mengeluarkan klaim kesahihannya secara sepihak. Temuan di lapangan membuktikan bahwa pihak legislatif dan pihak eksekutif memberikan klaim bahwa terhadap Perda itu telah dilakukan proses sosialisasi. Akan tetapi, pihak masyarakat yang terdiri atas kelompok wartawan, LSM, tokoh masyarakat dan masyarakat umum lainnya punya klaim yang berbeda. Mereka tidak tahu bagaimana Perda itu disosialisasikan. Mereka juga tidak tahu dalam bentuk apakah sosialisasi itu dilakukan mereka juga tidak tahu atas inisiatif dari manakah Perda itu dimunculkan.

Meski pada dasarnya mereka setuju bahwa substansi Perda itu adalah untuk meningkatkan PAD (Pendapatan Asli Daerah) dan untuk menyelamatkan lingkungan, tapi yang masih menjadi pertanyaan mereka adalah pihak siapakah yang diuntungkan oleh Perda itu. Pertanyaan ini mengemuka karena di Kabupaten 
Luwu Timur itu ada sebuah perusahaan besar yang menghasilkan limbah padat. Limbah pada itu bernilai ekonomis, dan untuk mengelola dibutuhkan persyaratan administratif yang mungkin sulit bisa dipenuhi oleh masyarakat biasa.

Kedua, eksklusivitas pembahasan persoalan kepublikan. Mengacu pada konsep public sphere, ruang publik pada dasarnya harus bersifat inklusif. Para peserta diskusi senantiasa mengaitkan kepentingan masyarakat yang lebih luas dan objek yang didiskusikannya dapat akses oleh siapa saja.

Pada kasus perencanaan dan pembahasan Perda No. 03 di Luwu Timur ini ditemukan bahwa di sana memang sudah ada upaya untuk melibatkan masyarakat, namun kelompok masyarakat yang ikut dilibatkan itu sangat terbatas (eksklusif). Eksklusifitas ini dapat berdampak pada lambannya atau gagalnya proses sosialisasi di satu sisi, dan rendahnya kepentingan publik yang terwakilkan di sisi lain.

Ketiga, efektifitas komunikasi yang masih rendah. Efektifitas komunikasi biasanya biasanya ditentukan oleh beberapa hal, antara lain oleh: seberapa sering sebuah pesan itu dikomunikasikan; seberapa cocok media komunikasi yang dipilih, dan seberapa tepat media itu mengkomunikasikan pesan komunikasinya kepada masyarakat yang diajak berkomunikasi.

Dalam kasus Perda No. 03 Tahun 2007 tentang Limbah Padat di Luwu Timur, ditemukan bahwa kuantitas dan frekuensi instansi terkait dalam mensosialisasikan Perda itu masih sangat rendah. Ini misalnya saja hanya ditulis dalam spanduk atau foto di tempat-tempat yang jauh dari konsentrasi pandangan masa. Karena itu, hal yang paling terjadi adalah ketidaktahuan masyarakat tentang proses pembuatan Perda, substansi Perda, dan pelaksanaan Perda itu.

Dari uraian di atas dapat dikatakan bahwa analisis public sphere terhadap masyarakat transisional memiliki penjelasannya sendiri. Ini karena tumbuhnya public sphere dalam masyarakat transisional adalah bagian yang tak terpisahkan dari proses transisi itu sendiri. Karena itu, menurut Robert Dahl, gradualisme, moderasi, dan kompromi adlah kunci keberhasilan transisi ke arah demokrasi. Public sphere dalam masyarakat transisional adalah public sphere yang semu alias belum murni (pseudo-public sphere). Dalam arti bahwa di sana ada sebuah persoalan yang menjadi bahan pembicaraan masyarakat di berbagai tempat, namun ketika persoalan itu ingin diupayakan solusinya yang melambangkan adanya consensus public, ternyata partisipasi mereka terputus di tengah jalan. Masyarakat tidak ikut ambil bagian yang signifikan dalam proses lahirnya konsensus publik itu.

Hal lain yang perlu disadari pula bahwa kesadaran masyarakat akan hak-hak publiknya dalam demokrasi masih rendah. Pada satu sisi, kesadaran yang rendah ini melahirkan sikap antipasti masyarakat terhadap urusan publiknya, tetapi pada isis lain 
masyarakat juga kerapkali mengungkapkan aspirasi penolakannya melalui demonstrasi yang kerap kali hanya dilatarbelakangi oleh emosi kejengkelan dan amarah, bukan melalui argumentasi yang logis.

Padahal, public sphere mestinya melahirkan masyarakat yang komunikatif. Menurut Habermas, masyarakat yang komunikatif itu adalah masyarakat yang mengedepankan argumentasi, entah dalam bentuk kritik atau diksursus, bukan melalui revolusi dengan kekerasan. Kalau melihat perkembangan realitas di Indonesia secara keseluruhan, khususnya di bidang demokrasi politik, memang ada perkembangan yang cukup menggembirakan. Ini terjadi pada tingkat organisasi atau institusi. Institusi atau organisasi negara sudah jauh lebih komunikatif dibanding dengan apa yang terjadi sekian tahun lalu. Kenyataan ini sebetulnya merupakan celah yang cukup bagus untuk dijadikan alasan atau harapan lahirnya ruang publik yang sehat. Tapi karena memang persoalan ekonomi yang belum cenderung membaik, akibatnya peluang demokrasi yang sudah mulai terbuka itu belum termanfaatkan secara optimal.

\section{Tantangan Bagi Masyarakat Transisional}

Hal yang paling umum dalam masyarakat transisi adalah adanya keinginan untuk menolak hal-hal yang lama, di satu sisi, dan adanya keterikatan terhadap tradisi lama yang belum bisa sepenuhnya ditinggalkan, di sisi lain. Tarik menarik antara keinginan untuk meraih hal-hal baru dan ketidaksanggupan untuk melepaskan dari hal-hal yang lama, biasanya telah memunculkan tanda tanya masa depan yang belum pasti. Artinya, di masa depan proses transisi yang dihadapi masyarakat Luwu Timur dalam kaitannya dengan perkembangan demokrasi itu tidak bisa dijawab dengan penjelasan yang tunggal dan definitif. Transisi ini bisa menghasilkan perubahan kearah yang lebih buruk atau mungkin hanya menghasilkan perubahan yang "jalan di tempat". Terkait dengan itu, mengarah kemanakah proses transisi demokrasi yang sedang berlangsung di Indonesia pada umumnya dan Luwu Timur pada khususnya?

Sebab, sebagaimanapun, arah proses transisi ini mau tidak mau akan menimbulkan implikasi khusus pada perkembangan ruang public. Perkembangan ruang publik akan semakin buruk bila transisi ini mengarah ke yang lebih buruk, dan sebaliknya, perkembangan ruang publik akan semakin bagus apabila transisi ini mengarah ke arah yang lebih baik (semakin demokratis). Dalam kaitannya denga kasus Luwu Timur, konsep public sphere akan semakin menjadi acuan dalam proses penentuan konsensus publik, apabila:

a. Pihak eksekutif dalam pemerintahan mulai mengikis tradisi feodal dan menggantikannya dengan tradisi demokrasi yang modern.

b. Pihak legislatif benar-benar memainkan peranan dan fungsi 
yang diembannya untuk mendengarkan aspirasi rakyat.

c. Pihak masyarakat meningkatkan kesadaran aakn hak-hak publiknya dalam berpartisipasi aktif untuk ikut menentukan kebijakan publik.

d. Pihak media benar-benar berusaha untuk tidak meninggalkan fungsi awalnya, yaitu untuk menjadi sarana terbentuknya ruang public yang benar-benar merepresentasikan kepentingan publik, bukan kepentingan segelintir kelompok.

Sebaliknya, ruang publik akan menghadapi ancaman serius apabila: pemerintah daerah justru menggunakan senjata otonomi daerah untuk mengukuhkan posisinya sebagai raja-raja kecil, pihak legislatif mengabaikan persoalan yang diperbincangkan secara umum di masyarakat atau menjadi perwakilan segelintir kelompok, pihak pers memanipulasi realitas sosial demi kepentingan kelompok, pihak masyarakat acuh tak acuh atas hakhaknya untuk berpartisipasi dalam proses penentuan kebijakan publik.

Selain itu tantangan yang dihadapi masyarakat transisional, bukan saja demokrasi yang menjadi lahan subur bagi tumbuhnya ruang publik. Pengalaman empiris beberapa negara menujukkan bahwa antara demokrasi dan ekonomi seringkali tidak memiliki hubungan yang paraler. Tidak semua negara demokratis itu ekonominya otomatis maju. Sebaliknya juga begitu. Padahal, peranan ekonomi bagi demokrasi sangatlah menentukan. Masyarakat transisional bisa berubah ke yang lebih tidak demokratis apabila pemerintah gagal mengembangkan kekuatan ekonomi. Ini juga bukti bahwa untuk menumbuhkan ruang publik dibutuhkan juga upaya-upaya untuk memperbaiki kekuatan ekonomi. Sayangnya, persoalan ini tidak banyak disinggung, baik oleh Habermas sendiri atau yang lain.

Hal yang paling menonjol dari masyarakat transisional seperti Indonesia ini, adalah terbukanya ruang kebebasan yang jauh lebih luas dari era sebelumnya. Tapi pada saat yang sama belum terlihat kemampuan yang dapat diandalkan untuk mengelola kebebasan itu. Masyarakat sudah terbebas dari keterpasungan kekuasaan (feodalisme) akan tetapi masyarakat juga belum siap untuk menjadi merdeka dalam arti yang sebenarnya. Hal ini pada tingkat riil kerap menimbulkan praktekpraktek untuk mendemontrasikan kebebasan hanya untuk kebebasan yang tidak disadari bahw itu telah memperlambat proses menuju demokrasi atau modern. Di pihak lain, ketidaksiapan untuk merdeka itu juga ditunjukkan dalam bentuk keantipatian terhadap tuntutan keadaan untuk berubah, baik pada pemerintah atau pada masyarakat.contoh nyata adalah rendahnya kuriositas dan hasrat masyarakat untuk melibatkan diri pada aktivitas-aktivitas yang dapat menyemangati munculnya ruang publik yang berbobot bagi kehidupan sosial. Ini memang terkait dengan persoalan ekonomi dan mental 
sekaligus. Dari pihak pemerintah juga terlihat masih belum mampu menyediakan fasilitas dan aksesibilitas kepada masyarakat agar lebih "aware" lagi terhadap hak-hak publiknya.

Artinya, apapun bahasanya, masyarakat transisional sebetulnya membutuhkan konsolidasi kekuatan reformasi agar perjalanan menuju destinasi yang dinginkan tidak berhenti di persimpangan jalan. Untuk merealisasikan konsolidasi kekuatan ini tentu dibutuhkan transformasi penjelasan, konsep, pengetahuan, informasi, teori, temuan-temuan dan lain-lain. Oleh karena itu masih diperlukan lebih banyak lagi studi serupa di daerah lain untuk menghasilkan temuan kasus atau identifikasi masalah terkait dengan otonomi atau masyarakt transisional yang bisa didekati dengan teori-teori ilmu sosial.

\section{KESIMPULAN}

Public sphere dalam masyarakat transisional, dalam hal ini masyarakat Luwu Timur, adalah public sphere yang semu alias belum murni (pseudo-public sphere). Dalam arti, di sana memang ada persoalan yang menjadi bahan pembicaraan masyarakat, tapi ketika persoalan itu diupayakan solusi yang melambangkan adanya consensus public (di luar perwakilan mereka di legislatif), ternyata partisipasi mereka tidak tersalurkan secara maksimal. Partispasi masyarakat dalam perumusan Perda Limbah Padat itu bisa dikatakan tidak signifikan.
Masyarakat Luwu Timur masih berasumsi bahwa opini publik mereka tidak punya peranan yang signifikan dalam menentukan kebijakan publik. Kesadaran masyarakat akan hak-hak demokratisnya masih rendah. Kalau dikembalikan pada konsep Habermas tentang public sphere, ini memang terkait dengan banyak hal. Satu di antaranya adalah terkait dengan akses dan distribusi informasi. Masyarakat masih sulit mengakses informasi yang terkait dengan kehidupan publik secara riil. Pada saat yang sama, pihak pemerintah pun kesulitan mendistribusikan informasi yang dibutuhkan masyarakat.

Kalau mengacu pada aturan pemerintah tentang alur pembuatan Perda, proses perumusan Perda sebenarnya sudah sesuai dengan aturan yang ditetapkan pemerintah. Hanya saja, masyarakat masih merasakan adanya agenda tersembunyi di balik rumusan Perda itu. Salah satu penyebab munculnya perasaan itu adalah karena aspek sosialisasi wacana perumusan Perda tersebut masih lemah dan kurang maksimal, baik sebelum dibahas maupun sesudah dirumuskan.

Berdasarkan uraian di atas, kalau mengacu pada konsep public sphere, memang ditemukan beberapa unsur yang telah memenuhi beberapa ide pokok Habermas tentang public sphere itu. Persoalan limbah padat telah menjadi perbincangan umum di masyarakat Luwu Timur di beberapa tempat. Namun, ketika sudah sampai pada perumusan kebijakan untuk publik, masyarakat masih belum punya akses untuk berpartisipasi dalam 
menentukan kebijakan publik dalam kehidupan mereka sehari-hari. Karena itu, tidak sedikit kelompok masyarakat yang berasumsi bahwa substansi dalam Perda No. 03 Tahun 2007 itu memang diangkat dari persoalan riil yang diperbincangkan oleh masyarakat. tetapi konsensusnya atau kebijakan publik yang terkait dengan persoalan itu tidak lahir dari masyarakat atau tidak melibatkan masyarakat luas. Konsensus dalam Perda itu lahir dari pihak eksekutif dan pihak legislatif.

Masyarakat Luwu Timur dalam konteks pembentukan Perda No. 03 Tahun 2007 tentang Limbah Padat, belum bisa berpartisipasi secara penuh, baik partisipasi politik maupun sosial. Kesadaran masyarakat Luwu Timur akan hak-hak demokrasinya juga masih rendah. Mayarakat Luwu Timur juga belum bisa melepaskan dirinya dari budaya feodalisme dan berubah menjadi masyarakat yang rasional. Mereka masih berasumsi bahwa opini public mereka tidak punya peran signifikan dalam pembentukan kebijakan publik.

Dalam kacamata Habermas, konsep Public sphere memiliki kedudukan yang penting dalam pembentukan masyarakat yang demokratis. Namun begitu, kesuksesan penerapannya tidak bisa bersifat tunggal, tapi tergantung pada berbagai kondisi-suasana dalam suatu masyarakat. Konsep public sphere Habermas tidak sepenuhnya bisa diterapkan di negara-negara yang masih menerapkan sistem feodal. Proses pembentukan public sphere di negara-negara maju yang digambarkan
Habermas tidak sama persis dengan formasi di Indonesia. Namun demikian, public sphere merupakan wahana yang penting dalam pembentukan masyarakat yang demokratisasi. Kesehatan public sphere juga merupakan indikasi kesehatan demokrasi di suatu negara.

Dengan mengacu pada gagasan gradualisme McKee (2005), ruang publik yang mengemuka di Kabupaten Luwu Timur adalah proses menuju realisasi public sphere sebagaimana yang digagas oleh Habermas. Gradualisme ini tidak hanya terjadi pada tingkat birokrasi pemerintah, melainkan terjadi pula pada tingkat kesadaran masyarakat akan hak-hak publiknya.

\section{DAFTAR PUSTAKA}

Dahl, Robert A. 1993. Demmokrasi dan Para Pengkritiknya. Yayasan Obor Indonesia

Habermas, Jurgen. 1997. The Structural Transformation of the Public Sphere. Massachusetts: The MIT Press.

Habermas, Jurgen. 1987. The Theory of Communicative Action, Volume 1: Reason and Rationalization, Boston: Beacon Press.

Habermas, Jurgen. 1987. The Theory of Communicative Action, Volume 2: Lifeword and System: Critique of Funcionalist Reason.

Hardiman, Budi F. 1993. Menuju Masyarakat Komunikatif. Yogyakarta: Penerbit Kanisus. 
Mckee, Alan. 2005. The Public Webster, Frank. 1995. Theories of Sphere: An Introduction. Cambridge, uk: Cambridge University Press Information Society. London: Routledge.

Undang-Undang No. 32 Tahun 2004, Tentang Pemerintahan Daerah.

Littlejohn, Stephen W. 2002. Ed. Theories of Human

Communication. Belmont, CA: Wadwort Thomson Learning. Tahun 2007, Tentang Limbah Padat.

Toulouse, Chris et al. 1998. The Time Magazine, 26 April 2004. Polities of Cyberspace. London: Routledge. 